\section{School trajectory and teenage pregnancy in three Brazilian state capitals}

\author{
Trajetória escolar e gravidez na adolescência \\ entre jovens de três capitais brasileiras
}

\author{
1 Instituto de Saúde Coletiva, \\ Universidade Federal da \\ Bahia, Salvador, Brasil. \\ Correspondence \\ M. C. C. Almeida \\ MUSA - Programa Integrado \\ de Pesquisa e Cooperação \\ Técnica em Gênero e Saúde. \\ Instituto de Saúde \\ Coletiva, Universidade \\ Federal da Bahia. \\ Rua Basílio da Gama s/n \\ Campus Universitário \\ Canela, Salvador, $B A$ \\ 40110-040, Brasil. \\ musa@ufba.br \\ mcca@ufba.br
}

\section{Abstract}

This paper describes the relationship between school trajectory and incidence of teenage pregnancy. A cross-sectional residence-based questionnaire was applied, interviewing 4,634 youth ages 18 to 24 years, selected through a stratified three-stage sample. For the present study, young people ages 20 to 24 years (65.6\%) were chosen, with teenage pregnancy rates of $29.5 \%$ for females and $21.4 \%$ for males (in relation to their partners). Sexual debut was reported by $87 \%$ of women and $95.3 \%$ of men. The majority of young people reported irregular school trajectory, with $39 \%$ enrolled in school at the time of the study. Nearly half of those who had interrupted their studies at least once reported a teenage pregnancy. The main reasons for interrupting their studies were pregnancy and children for women and work for men. School dropout due to teenage pregnancy was mentioned by $40.1 \%$ of women for whom the outcome of pregnancy was a child. However, 20.5\% had already dropped out of school before becoming pregnant.

Pregnancy in Adolescence; Educational Status; Gender Identity; Sexuality
Maria da Conceição C. Almeida ${ }^{1}$

Estela M. L. Aquino ${ }^{1}$

Antoniel Pinheiro de Barros 1

\section{Introduction}

Teenage pregnancy has been described as a social and public health problem that merits special attention in policies targeting this age group. In a literature survey covering the 1990s, pregnancy appears as the second most frequent issue in studies on adolescence in Brazil, next only to sexuality 1 .

The visibility of teenage pregnancy is attributed especially to the decline in the total fertility rate, which since 1980 has dropped progressively in all regions of Brazil, particularly due to the use of contraceptive methods and recourse to abortion 2,3. However, most of this decline is from women in the 25-30-year bracket, with only minor increases or decreases recorded in the 15-19-year bracket 3,4.

Adolescent fertility is commonly considered "early" on the grounds that gestation during this period anticipates the "socially institutionalized movements for reproduction, thereby entailing a number of unwanted results for the woman and children" 5 (p. 110). However, the debate in the socio-anthropological field highlights that expectations related to age can change socially and historically, and that for a long time the 14-18-year period was considered the ideal time for women to bear children 6 . Currently, women and especially young women are expected to focus on their studies and prepare themselves for better future entry into the work 
market, so that age at entry into childbearing life is preferably postponed. From this perspective, teenage pregnancy is generally held responsible for school dropout and thus for the loss of better employment opportunities 4 .

Gupta \& Leite 4 analyzed the results of demographic surveys in Northeast Brazil in 1986, 1991, and 1996 and concluded that 15-19-yearold girls with low educational levels consistently showed at least twice the probability of having a child as compared to those with more schooling. Education was also heavily associated with postponing the birth of the first child among adolescent girls in the Northeast. During the three years studied (1986, 1981, and 1996), even controlling for age and other economic and cultural characteristics, the impact of educational level remained: adolescents with four years of schooling or less had at least twice the probability of having a child before reaching 20, as compared to those with at least five years of schooling 4 .

Souza 7, analyzing Brazilian data from the survey by the Family Welfare in Brazil (BEMFAM - Bem-Estar Familiar no Brasil) in 1996 8, showed that $51 \%$ of $15-19$-year-old girls with no schooling were already mothers, and that $13 \%$ of $15-24$ year-old women reported ever having dropped out of school because of marriage, pregnancy, or childcare. According to the author 7 (p. 78) one can "raise the hypothesis that there is a two-way causality in the relationship between motherhood and education", contending that it is difficult to determine to what extent lower educational level causes higher fertility, and that the drop in fertility as women's educational level increases "may merely express the effect of other variables positively related to education that are actually the direct determinants of fertility" 7 (p. 78).

In the reviewed articles there is an evident correlation between the events, without an investigation into the order in which they occurred. Stern \& García 9 call attention to the fact that for many adolescents, especially in underdeveloped countries, pregnancy occurs after dropping out of school, thus justifying studies to adequately analyze this temporal relationship. One should emphasize the lack of analyses comparing adolescents from different social strata, which could identify important elements for the discussion on the relationship between adolescent childbearing and the perpetuation of poverty. In addition, knowledge on the issue also lacks the perspective of male partners and the relationship between adolescent fatherhood and the boys' school trajectory.
The current article is part of the output from the research project entitled Teenage Pregnancy: A Multi-center Study on Youth, Sexuality, and Reproduction in Brazil (GRAVAD Research Project), in three Brazilian State capitals: Salvador, Rio de Janeiro, and Porto Alegre. The basic premise is that adolescence is a transition from childhood to adulthood in which the individual is progressively emancipated from control by the family and school 10 . It is intended to describe the relationship between school trajectory characteristics for young men and women and the occurrence of teenage pregnancy (in the girls themselves or in the female partners of the boys), with an exploratory focus on the alleged reasons and the time at which school dropout occurs.

\section{Methodology}

The study population in the GRAVAD Research Project consists of young males and females from the three cities, ranging from 18 to 24 years of age at the time of the survey. The selection used a three-stage stratified probabilistic sample, thus ensuring that it is representative of the overall population in the target age group. The sample size of 1,500 interviews per city was calculated on the basis of existing estimates of history of pregnancy in women at 18 and 19 years, corresponding respectively to $25.3 \%$ and $34.8 \%$ in 19968 .

In order to guarantee adequate geographic dispersion, during the first stage a stratified random sample of census tracts was selected, previously grouped in five strata according to mean income and head-of-family's schooling. During the second stage, based on a list of households produced to identify those with youth in the target age bracket, 33 households from each census tract were selected randomly, considering a loss rate of approximately $20 \%$. During the third stage, a young person was selected among the eligible residents in the selected household, using as the criterion the individual whose birthday (month and day) was the first of the year (when the birthdays coincided, first-name alphabetical order was used as the runoff criterion).

Data were produced using face-to-face interviews with a previously tested questionnaire that reconstructed the individuals' school, job, and affective/sexual histories. The vast majority of the interviewers, male and female, were students and/or professionals from the human sciences and with similar ages to those of the interviewees, which facilitated their interaction. 
All questionnaires were reviewed by the supervisory team. A $20 \%$ sample was also selected for reviewing specific questions (by telephone or returning to the household), thus ensuring the survey's quality.

The database was constructed by double keying-in, using Epi Info version 6.04b (Centers for Disease Control and Prevention, Atlanta, USA). Due to the sampling plan's complexity, the analysis used Stata version 8 (Stata Corporation, College Station, USA), which allowed incorporating the effect of the sample design and the relative weights for each unit, obtaining estimates with reliable parameters. Weights were calculated based on the unit selection probabilities in each stage.

Decentering the 10-19-year age bracket (usually defined as adolescence 11,12) to constitute the study population allowed recalling a pregnancy that had occurred in a previous period but that was sufficiently close to be remembered. However, for analytical purposes, teenage pregnancy was defined as that occurring in females less than 20 years of age, in order to allow comparison with other studies. The choice was made to analyze only the data pertaining to interviewees 20 to 24 years of age, excluding those less than 20 years old, who could still experience a pregnancy in this age bracket. In addition, to analyze the school histories, all young people in this age bracket must have concluded at least middle school, which together with preschool and elementary education comprise the basic level of schooling in Brazil according to the National Law on Educational Guidelines and Foundations (LDB) 13.

As for the pregnancy outcome, the study excluded youth who reported spontaneous abortion and those who were pregnant (or whose partners were pregnant, in the case of males) at the time of the interview. Different cutoff points were used for age at sexual debut for girls and boys, due to the previously observed differences for this phenomenon in females and males.

The selected questions related to socio-demographic information, affective and sexual history, childbearing history, and school trajectory and were used to construct indicators on age-grade lag, repetition, and dropout.

The age-grade lag indicator was defined as: $[$ Lag $=($ age $)-($ years of school $)-(7)] 10$. This indicator was further split into four others of the yes/no type, according to different cutoff points in school trajectory: enrollment, completion of the $4^{\text {th }}$ grade, completion of the $8^{\text {th }}$ grade, and completion of secondary school. Finally, the study created a summary indicator for the lag at any of these specific moments.
Based on the information concerning the number of temporary dropouts and repetitions, the variables were reclassified as yes or no. The indicators for age-grade lag, repetition, and temporary dropout produced eight types of school trajectory. In this study, trajectory was defined according to its "objective dimension" 14 (p. 5) as the "series of social positions occupied over the course of one's life, measured by statistical categories and condensed in a general trend" 14 (p. 5). School histories were thus summarized in an indicator with three categories: irregular with temporary dropout, irregular without temporary dropout, and regular.

Dropout was defined as interrupting one's studies at any time before having completed secondary school. An indicator was created which reflects the relationship between the timing of pregnancy and that of school dropout, classified as: (a) dropout before pregnancy: age at pregnancy greater than age at dropout; (b) dropout at the time of or after pregnancy: age at pregnancy less than or equal to age at dropout; and (c) non-dropout (even having become pregnant).

As for the analytical procedures, univariate and bivariate analyses were used first to describe the selected variables through simple frequency distributions and cross-analyses in order to characterize the study population. Differences between proportions were tested for statistical significance using Pearson's $\chi^{2}$, with second-order correction according to Rao \& Scott at the $5 \%$ level.

All of the ethical procedures were reviewed and approved by the Research Ethics Committees of the respective universities. An Informed Consent Form was read to each interviewee before the questionnaire was applied and signed at the end. The study protocol also ensured the interview's privacy, without the presence of third parties older than four years.

\section{Results}

\section{Study population}

A total of 4,634 young women and men were interviewed, ranging from 18 to 24 years of age, of whom 3,042 (65.6\%) were selected for this study, ranging from 20 to 24 years. Of these, $53.2 \%$ were women and $46.8 \%$ men. The proportion of young people who reported a pregnancy before 20 years of age was $29.5 \%$ (95\%CI: $26.3-33.0$ ) for women and $21.4 \%$ (95\%CI: 18.3-24.9) for men in relation to their female partners. 
At the time of the interview, $39 \%$ of the subjects were still in school, although the vast majority of both genders had irregular school histories, with or without temporary dropout ( $69.9 \%$ of the women and $76.3 \%$ of the men). Women had more regular school trajectories (30.1\%) than men $(19.8 \%)$. Salvador had the highest proportion of youth with irregular school histories $(82.5 \%$ of females and $87.8 \%$ of males), contrasting with Porto Alegre, where $56.2 \%$ of the girls and $69.4 \%$ of the boys were in this situation. Rio de Janeiro occupied an intermediate position with $64.8 \%$ and $78.8 \%$, respectively (data not shown).

Considering seven years as the basic legal age for enrollment in elementary school in Brazil $10,8.8 \%$ of girls and $15.5 \%$ of boys already entered elementary school with an age-grade lag. The lag increased by the time they completed the fourth and eighth grades, both for girls (27.3\% and $38.5 \%$, respectively) and boys (36.6\% and $47.4 \%$, respectively). However, the figures were slightly lower for completion of middle school (33\% for girls and $42.2 \%$ for boys), even though they were still high (data not shown).

\section{Social determinants of school trajectory}

Before examining the relationship between progress in school and pregnancy, we will describe the different youth profiles according to type of educational attainment. The latter was inversely proportional to monthly per capita family income, i.e., those with lower income were overrepresented in the groups with irregular school records (with temporary dropout), and even more so among those with irregular records that included temporary dropout (Table 1). Likewise, both girls and boys whose mothers had incomplete elementary schooling were more prone to interrupting their schooling. Inversely, when mothers had completed secondary or university education, the youth tended to have more regular school trajectory.

Black students of both genders were underrepresented in the group with regular school trajectory ( $16.1 \%$ of girls and $8.4 \%$ of boys), contrasting with white girls and boys, who tended to have more regular trajectory $(62.8 \%$ and $67.3 \%$ ). Worthy of note is that females who were working at the time of the interview tended to have more regular trajectory $(63.6 \%)$ as compared to those who were not working, the majority of whom had interrupted their studies (54.5\%). On the other hand, those in the 15-18year bracket with greater responsibility for housework were less represented in the group with regular school trajectory $(7.2 \%$, as shown in Table 1). Interestingly, for boys, paid work outside of the home and household work were not associated with regular school attainment.

\section{School trajectory and sexuality}

The GRAVAD Research Project focused on understanding the phenomena of youth pregnancy and parenthood, and young people were thus interviewed concerning their life histories in relation to socialization and sexual debut. Having received their first information on pregnancy and contraception from the mother was more frequent in girls with regular school trajectory (59.1\%, see Table 2). The school also appears as an important source of information among girls and is less frequently cited by those with irregular school progress, especially those with a history of dropout. Boys showed a similar gradient in this relationship (Table 2).

Considering the experience of "making out" (ficar, in Portuguese) and dating (namorar) as milestones in the passage to adult sex life, according to the current study, the age when girls began their first steady dating was not associated with the type of progress in school, as it was for men. Those with the most regular school trajectory were those who reported never having dated steadily or who began steady dating at a later age (Table 2).

The vast majority of youth were already sexually experienced at the time of the interview ( $87 \%$ of girls and $95.3 \%$ of boys). As a whole, boys had their sexual debut earlier than girls. For both genders, irregular school trajectory was associated with earlier sexual debut (Table 2).

Use of contraceptive methods during first sexual relations was significantly more frequent among both males and females with regular school trajectory (Table 2).

\section{School trajectory and dropout in relation to pregnancy}

Nearly half of the youth who had interrupted their studies reported at least one reproductive episode during adolescence, a much higher proportion than those with regular school trajectory or even as compared to those who had repeated grades but stayed in school. Among boys with regular school trajectory, the pregnancy rate with their partners is practically negligible (Figure 1).

The majority of youth with a history of teenage pregnancy reported only one episode ( $57.7 \%$ of girls and $63.5 \%$ of boys). The outcome of the first pregnancy was associated with the type of school trajectory: $83.1 \%$ of youth with 
Distribution of youth 20 to 24 years of age by type of school trajectory, socio-demographic characteristics, and gender, Porto Alegre, Rio de Janeiro, Salvador, Brazil.

\begin{tabular}{|c|c|c|c|c|c|c|c|c|c|}
\hline \multirow[t]{3}{*}{ Socio-demographic characteristics } & \multicolumn{8}{|c|}{ Type of school trajectory } & \multirow[t]{3}{*}{ p-value } \\
\hline & \multicolumn{2}{|c|}{$\begin{array}{l}\text { Irregular with } \\
\text { temporary dropout }\end{array}$} & \multicolumn{2}{|c|}{$\begin{array}{l}\text { Irregular without } \\
\text { temporary dropout }\end{array}$} & \multicolumn{2}{|c|}{ Regular } & \multicolumn{2}{|c|}{ Total } & \\
\hline & $n$ & $\%$ & $n$ & $\%$ & $\mathrm{n}$ & $\%$ & $\mathrm{n}$ & $\%$ & \\
\hline \multicolumn{10}{|l|}{ Females } \\
\hline $\begin{array}{l}\text { Monthly per capita family income }(\mathrm{R} \$)^{*} \\
\quad \leq 90.00 \\
91.00-180.00 \\
181.00-540.00 \\
>540.00\end{array}$ & 462 & $\begin{array}{l}24.0 \\
27.2 \\
35.5 \\
13.2\end{array}$ & 461 & $\begin{array}{l}14.0 \\
21.1 \\
43.3 \\
21.6\end{array}$ & 425 & $\begin{array}{r}5.3 \\
9.5 \\
33.1 \\
52.1\end{array}$ & 1,348 & $\begin{array}{l}15.0 \\
19.8 \\
34.4 \\
27.7\end{array}$ & 0.0000 \\
\hline $\begin{array}{l}\text { Mother's schooling } \\
\text { Incomplete elementary } \\
\text { Complete elementary } \\
\text { Complete or incomplete } \\
\text { secondary/University }\end{array}$ & 434 & $\begin{array}{l}58.7 \\
19.4 \\
21.9\end{array}$ & 448 & $\begin{array}{l}44.6 \\
22.0 \\
33.4\end{array}$ & 425 & $\begin{array}{l}20.7 \\
15.3 \\
64.0\end{array}$ & 1,307 & $\begin{array}{l}42.1 \\
19.0 \\
38.9\end{array}$ & 0.0000 \\
\hline $\begin{array}{l}\text { Currently working } \\
\text { Yes } \\
\text { No }\end{array}$ & 462 & $\begin{array}{l}50.9 \\
49.1\end{array}$ & 461 & $\begin{array}{l}54.5 \\
45.5\end{array}$ & 425 & $\begin{array}{l}63.6 \\
36.4\end{array}$ & 1,348 & $\begin{array}{l}55.9 \\
44.1\end{array}$ & 0.0256 \\
\hline $\begin{array}{l}\text { Participation in housework ( } 15 \text { to } 18 \text { years) } \\
\text { Principal person in charge } \\
\text { Shares equally with others } \\
\text { Helps out } \\
\text { No housework obligations }\end{array}$ & 457 & $\begin{array}{l}21.2 \\
29.1 \\
37.2 \\
12.5\end{array}$ & 461 & $\begin{array}{l}10.6 \\
26.3 \\
46.1 \\
17.0\end{array}$ & 424 & $\begin{array}{r}7.2 \\
15.6 \\
52.6 \\
24.6\end{array}$ & 1,342 & $\begin{array}{l}13.5 \\
24.1 \\
44.8 \\
17.6\end{array}$ & 0.0000 \\
\hline \multicolumn{10}{|l|}{ Males } \\
\hline $\begin{array}{l}\text { Monthly per capita family income }(\mathrm{R} \$)^{*} \\
\quad \leq 90.00 \\
91.00-180.00 \\
181.00-540.00 \\
>540.00\end{array}$ & 457 & $\begin{array}{l}19.4 \\
25.3 \\
40.2 \\
15.1\end{array}$ & 433 & $\begin{array}{r}9.5 \\
16.0 \\
43.8 \\
30.7\end{array}$ & 277 & $\begin{array}{r}0.7 \\
2.6 \\
40.2 \\
56.5\end{array}$ & 1,167 & $\begin{array}{l}12.4 \\
17.6 \\
41.4 \\
28.6\end{array}$ & 0.0000 \\
\hline $\begin{array}{l}\text { Mother's schooling } \\
\text { Incomplete elementary } \\
\text { Complete elementary } \\
\text { Complete or incomplete } \\
\text { secondary/university }\end{array}$ & 422 & $\begin{array}{l}57.2 \\
19.6 \\
23.2\end{array}$ & 410 & $\begin{array}{l}35.2 \\
21.3 \\
43.5\end{array}$ & 276 & $\begin{array}{l}16.9 \\
10.0 \\
73.1\end{array}$ & 1,108 & $\begin{array}{l}41.3 \\
18.2 \\
40.5\end{array}$ & 0.0000 \\
\hline $\begin{array}{l}\text { Color/Race }{ }^{\star \star \star} \\
\text { White } \\
\text { Brown (mixed-race) } \\
\text { Black }\end{array}$ & 410 & $\begin{array}{l}40.2 \\
29.1 \\
30.7\end{array}$ & 401 & $\begin{array}{l}50.7 \\
24.9 \\
24.4\end{array}$ & 270 & $\begin{array}{r}67.3 \\
24.3 \\
8.4\end{array}$ & 1,081 & $\begin{array}{l}49.3 \\
26.7 \\
24.0\end{array}$ & 0.0000 \\
\hline $\begin{array}{l}\text { Currently working } \\
\text { Yes } \\
\text { No }\end{array}$ & 457 & $\begin{array}{l}68.8 \\
31.2\end{array}$ & 432 & $\begin{array}{l}66.6 \\
33.4\end{array}$ & 277 & $\begin{array}{l}60.9 \\
39.1\end{array}$ & 1,166 & $\begin{array}{l}66.5 \\
33.5\end{array}$ & 0.4729 \\
\hline $\begin{array}{l}\text { Participation in housework ( } 15 \text { to } 18 \text { years) } \\
\text { Principal person in charge } \\
\text { Shares equally with others } \\
\text { Helps out } \\
\text { No housework obligations }\end{array}$ & 454 & $\begin{array}{r}5.7 \\
15.8 \\
51.8 \\
26.7\end{array}$ & 433 & $\begin{array}{r}2.9 \\
15.8 \\
48.0 \\
33.3\end{array}$ & 277 & $\begin{array}{r}2.4 \\
17.9 \\
47.4 \\
32.3\end{array}$ & 1,164 & $\begin{array}{r}4.1 \\
15.2 \\
49.6 \\
30.1\end{array}$ & 0.4380 \\
\hline
\end{tabular}

* Categories defined on the basis of the prevailing nationwide minimum wage ( $R \$ 180.00)$;

** Excludes $1.8 \%$ and $6.6 \%$ of the females who self-identified as yellow (Asian) and indigenous, respectively;

$\star \star \star$ Excludes $0.8 \%$ e $7.1 \%$ of the males who self-identified as yellow (Asian) and indigenous, respectively.

Source: GRAVAD Research Project, 2002. 
Table 2

Distribution of youth 20 to 24 years of age by type of school trajectory, selected characteristics at sexual debut, and gender, Porto Alegre, Rio de Janeiro, Salvador, Brazil.

\begin{tabular}{|c|c|c|c|c|c|c|c|c|c|}
\hline \multirow[t]{3}{*}{ Sexual debut } & \multicolumn{8}{|c|}{ Type of school trajectory } & \multirow[t]{3}{*}{$p$-value } \\
\hline & \multicolumn{2}{|c|}{$\begin{array}{l}\text { Irregular with } \\
\text { temporary dropout }\end{array}$} & \multicolumn{2}{|c|}{$\begin{array}{l}\text { Irregular without } \\
\text { temporary dropout }\end{array}$} & \multicolumn{2}{|c|}{ Regular } & \multicolumn{2}{|c|}{ Total } & \\
\hline & $\mathrm{n}$ & $\%$ & $\mathrm{n}$ & $\%$ & $\mathrm{n}$ & $\%$ & $\mathrm{n}$ & $\%$ & \\
\hline \multicolumn{10}{|l|}{ Females } \\
\hline $\begin{array}{l}\text { First information on pregnancy } \\
\text { and contraception }\end{array}$ & 461 & & 461 & & 425 & & 1,347 & & 0.0000 \\
\hline \multicolumn{10}{|l|}{ From mother } \\
\hline Yes & & 28.0 & & 47.6 & & 59.1 & & 44.0 & \\
\hline No & & 72.0 & & 52.4 & & 40.9 & & 56.0 & \\
\hline From school & 461 & & 461 & & 425 & & 1,347 & & 0.0014 \\
\hline Yes & & 26.6 & & 36.0 & & 44.1 & & 35.0 & \\
\hline No & & 73.4 & & 64.0 & & 55.9 & & 65.0 & \\
\hline Age at first dating (years) & 461 & & 460 & & 425 & & 1,346 & & 0.0794 \\
\hline$\leq 13$ & & 32.3 & & 33.4 & & 26.4 & & 30.9 & \\
\hline $14-15$ & & 42.4 & & 38.9 & & 35.9 & & 39.3 & \\
\hline$\geq 16$ & & 24.5 & & 25.4 & & 35.2 & & 28.0 & \\
\hline No dating or making out* & & 0.8 & & 2.3 & & 2.5 & & 1.8 & \\
\hline Previous sexual experience & 462 & & 461 & & 425 & & 1,348 & & 0.0026 \\
\hline Yes & & 92.7 & & 84.5 & & 82.9 & & 87.0 & \\
\hline No & & 7.3 & & 15.5 & & 17.1 & & 13.0 & \\
\hline Age at 1 st sexual relations (years) & 433 & & 385 & & 354 & & 1,172 & & 0.0002 \\
\hline$\leq 15$ & & 31.1 & & 18.3 & & 12.1 & & 21.5 & \\
\hline $16-17$ & & 32.2 & & 34.2 & & 28.5 & & 31.8 & \\
\hline$\geq 18$ & & 36.7 & & 47.5 & & 59.4 & & 46.7 & \\
\hline $\begin{array}{l}\text { Use of contraceptive method, } \\
1 \text { st sexual relations }\end{array}$ & 431 & & 383 & & 353 & & 1,167 & & 0.0000 \\
\hline Yes & & 59.8 & & 70.8 & & 82.6 & & 69.9 & \\
\hline No & & 40.2 & & 29.2 & & 17.4 & & 30.1 & \\
\hline \multicolumn{10}{|l|}{ Males } \\
\hline $\begin{array}{l}\text { First information on pregnancy } \\
\text { and contraception }\end{array}$ & 456 & & 433 & & 276 & & 1,165 & & 0.0123 \\
\hline \multicolumn{10}{|l|}{ From mother } \\
\hline Yes & & 36.7 & & 34.4 & & 52.0 & & 38.9 & \\
\hline No & & 63.3 & & 65.6 & & 48.0 & & 61.1 & \\
\hline From school & 456 & & 433 & & 276 & & 1,165 & & 0.0025 \\
\hline Yes & & 24.3 & & 37.3 & & 39.1 & & 31.6 & \\
\hline No & & 75.7 & & 62.7 & & 60.9 & & 68.4 & \\
\hline Age at first dating (years) & 455 & & 431 & & 276 & & 1,162 & & 0.0011 \\
\hline$\leq 13$ & & 40.7 & & 35.0 & & 23.8 & & 35.4 & \\
\hline $14-15$ & & 34.3 & & 35.3 & & 27.7 & & 33.3 & \\
\hline$\geq 16$ & & 22.4 & & 28.7 & & 43.8 & & 28.8 & \\
\hline No dating or making out* & & 2.6 & & 1.0 & & 4.7 & & 2.5 & \\
\hline Previous sexual experience & 455 & & 432 & & 277 & & 1,164 & & 0.4593 \\
\hline Yes & & 96.7 & & 94.1 & & 94.5 & & 95.3 & \\
\hline No & & 3.3 & & 5.9 & & 5.5 & & 4.7 & \\
\hline Age at 1 st sexual relations (years) & 442 & & 411 & & 263 & & 1,116 & & 0.0117 \\
\hline$\leq 15$ & & 32.4 & & 24.5 & & 14.7 & & 26.3 & \\
\hline $16-17$ & & 31.7 & & 44.3 & & 44.7 & & 38.4 & \\
\hline$\geq 18$ & & 35.9 & & 31.2 & & 40.6 & & 35.3 & \\
\hline $\begin{array}{l}\text { Use of contraceptive method, } \\
1 \text { st sexual relations }\end{array}$ & 435 & & 412 & & 259 & & 1,106 & & 0.0009 \\
\hline Yes & & 61.5 & & 65.2 & & 82.0 & & & \\
\hline No & & 38.5 & & 34.8 & & 18.0 & & & \\
\hline
\end{tabular}

Source: GRAVAD Research Project, 2002.

* Relation without commitment including sex or not. 
Proportion and $95 \%$ confidence interval $(95 \% \mathrm{Cl})$ of youth 20 to 24 years old who reported at least one pregnancy during adolescence, according to type of school trajectory and gender. Porto Alegre, Rio de Janeiro, Salvador, Brazil.

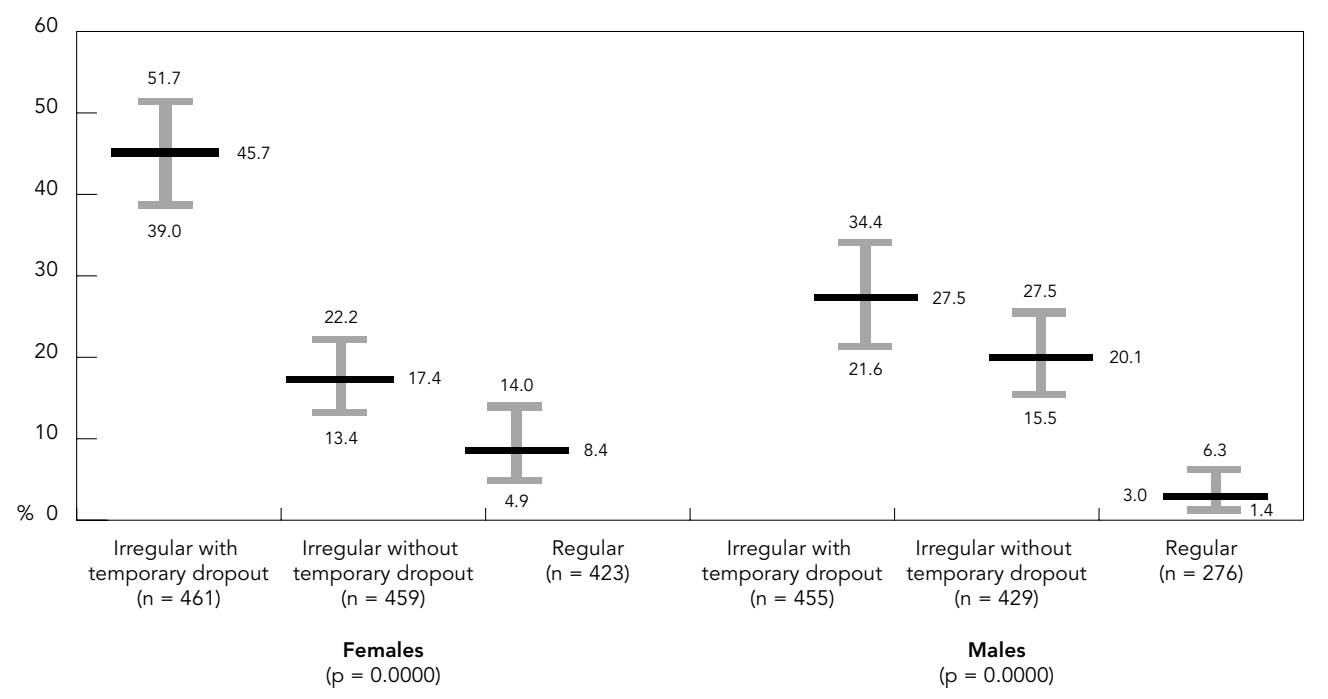

Source: GRAVAD Research Project, 2002.

irregular school records ended up with a child, while among those with regular school trajectory this proportion dropped to $58.7 \%\left(\chi^{2}=\right.$ $7.40, \mathrm{df}=1 ; \mathrm{p}=0.0074$ ), while the others opted for induced abortion (data not shown).

Among females, pregnancy before the age of 20 was inversely related to schooling, with a clear gradient, varying from $64.7 \%$ in those with incomplete elementary school to $4.9 \%$ in those with a university education. The same trend was true for males, but with a smaller difference between the strata (Table 3).

Repetition and temporary dropout are frequent events in the school history of males and females, and both show a direct association with pregnancy before 20 years of age. The pregnancy rate is higher among those with agegrade lag, but this is also true when the lag already existed upon entering elementary school.

The proportion of teenage pregnancy is clearly higher among temporary dropouts, especially girls $(60.1 \%)$. What distinguishes males from females is the fact that pregnancy and children were identified by girls as the main reason for the last interruption in the studies (among those reporting any reproductive episodes). In contrast, work is cited by males in general and females with a history of preg- nancy as the principal reason for dropping out of school (Figure 2).

When analyzing the relationship between school dropout and teenage pregnancy, the sequence in which the events takes place must be considered. Among low-income adolescents, a higher proportion dropped out during or after pregnancy, which is also true among boys who got their partners pregnant during adolescence (Table 4). Another social indicator (mother's schooling) was also associated with school dropout and teenage pregnancy only in girls; however, it is worthy of note that $75.5 \%$ of girls whose mothers had complete secondary or university education did not drop out of school despite becoming pregnant (Table 4).

Working at the time of pregnancy (more frequent among boys) was associated with school dropout, especially when they dropped out before the first reproductive episode. Marital status only influenced this situation for females. The proportion of youth who did not drop out of school despite pregnancy was higher among girls who were not married at the time and who remained unmarried. Interestingly, among girls who married at the time of the pregnancy or the interview, some $40 \%$ dropped out of school during or after pregnancy (Table 4). 
Pregnancy proportion before 20 years of age and $95 \%$ confidence interval $(95 \% \mathrm{Cl})$, according to school indicators and gender in youth 20 to 24 years of age, Porto Alegre, Rio de Janeiro, Salvador, Brazil.

\begin{tabular}{|c|c|c|c|c|c|c|}
\hline \multirow[t]{3}{*}{ School indicators } & \multicolumn{6}{|c|}{ Pregnancy before the age of 20} \\
\hline & \multicolumn{3}{|c|}{ Females } & \multicolumn{3}{|c|}{ Males* } \\
\hline & $\mathrm{n}$ & $\%$ & $95 \% \mathrm{Cl}$ & $n$ & $\%$ & $95 \% \mathrm{Cl}$ \\
\hline Overall proportion & 1,612 & 29.5 & $26.3-33.0$ & 1,414 & 21.4 & 18.3-24.9 \\
\hline \multicolumn{7}{|l|}{ Current school attainment } \\
\hline Incomplete elementary & 300 & 64.7 & $55.8-72.5$ & 304 & 37.7 & $28.3-48.1$ \\
\hline Complete elementary & 298 & 42.9 & $35.8-50.4$ & 307 & 26.1 & $19.5-33.8$ \\
\hline Complete secondary & 511 & 21.3 & $16.9-26.5$ & 413 & 14.3 & 10.1-19.9 \\
\hline Incomplete or complete university & 479 & 4.9 & $2.9-8.0$ & 364 & 7.2 & 4.4-11.7 \\
\hline \multicolumn{7}{|l|}{ Any repetition } \\
\hline Yes & 918 & 35.3 & $30.9-40.0$ & 933 & 25.3 & $21.3-29.8$ \\
\hline No & 675 & 21.5 & $17.7-25.3$ & 469 & 13.0 & $8.6-19.1$ \\
\hline \multicolumn{7}{|l|}{ Dropped out of school } \\
\hline Never dropped out & 946 & 14.4 & $11.9-17.2$ & 767 & 13.3 & $10.4-16.9$ \\
\hline Dropped out and later reenrolled & 292 & 35.8 & $28.4-44.1$ & 257 & 18.3 & $12.7-25.5$ \\
\hline Dropped out and did not reenroll & 360 & 61.4 & $53.6-68.6$ & 386 & 36.2 & $28.3-44.8$ \\
\hline \multicolumn{7}{|l|}{ Overall age-grade lag } \\
\hline Yes & 723 & 36.4 & $31.7-41.3$ & 738 & 26.5 & $22.3-31.2$ \\
\hline No & 630 & 10.3 & 7.3-14.4 & 432 & 5.3 & $3.3-8.4$ \\
\hline \multicolumn{7}{|l|}{$\begin{array}{l}\text { Age-grade lag upon enrolling } \\
\text { in elementary school }\end{array}$} \\
\hline Yes & 137 & 45.5 & $35.7-55.8$ & 146 & 36.7 & $25.2-49.9$ \\
\hline No & 1,340 & 26.4 & $22.7-30.4$ & 1,130 & 19.2 & $16.1-22.7$ \\
\hline \multicolumn{7}{|l|}{ School attendance ${ }^{\star \star}$} \\
\hline Completed elementary school & 520 & 20.3 & $16.4-24.8$ & 364 & 16.4 & $11.9-22.1$ \\
\hline Attending public/Private school & 670 & 16.8 & $13.1-21.4$ & 603 & 11.9 & $8.9-15.7$ \\
\hline Dropped out & 415 & 60.1 & $52.9-66.8$ & 447 & 35.4 & $28.2-43.3$ \\
\hline
\end{tabular}

* Got a partner pregnant at least once before the age of 20 .

** Six young people who had never attended school were excluded.

Source: GRAVAD Research Project, 2002.

Pregnancy outcome was only statistically associated with school dropout for girls. Among those whose pregnancy resulted in the birth of a child, $40.1 \%$ dropped out of school at this time, but another $20.6 \%$ had already dropped out before giving birth. On the other hand, of those who opted for induced abortion, $84.3 \%$ remained in school.

\section{Discussion}

Before discussing the results, some methodological aspects should be examined to contextualize the study's limits and possibilities. The data are from a study with a representative sample of girls and boys from three cities located in different regions of Brazil. The fact that it included males helps give visibility to adolescent fatherhood and its relationship to school indicators. The percentage of losses in this study $(14.8 \%)$ is considered relatively low for this type of study. In addition, the losses resulted mainly from difficult access to households in unsafe areas and absence of the selected youth after four visits to the household, while the percentage of refusals was negligible.

Since this was a cross-sectional study, the possibility of a recall bias should be discussed when analyzing past facts. Still, one may sup- 


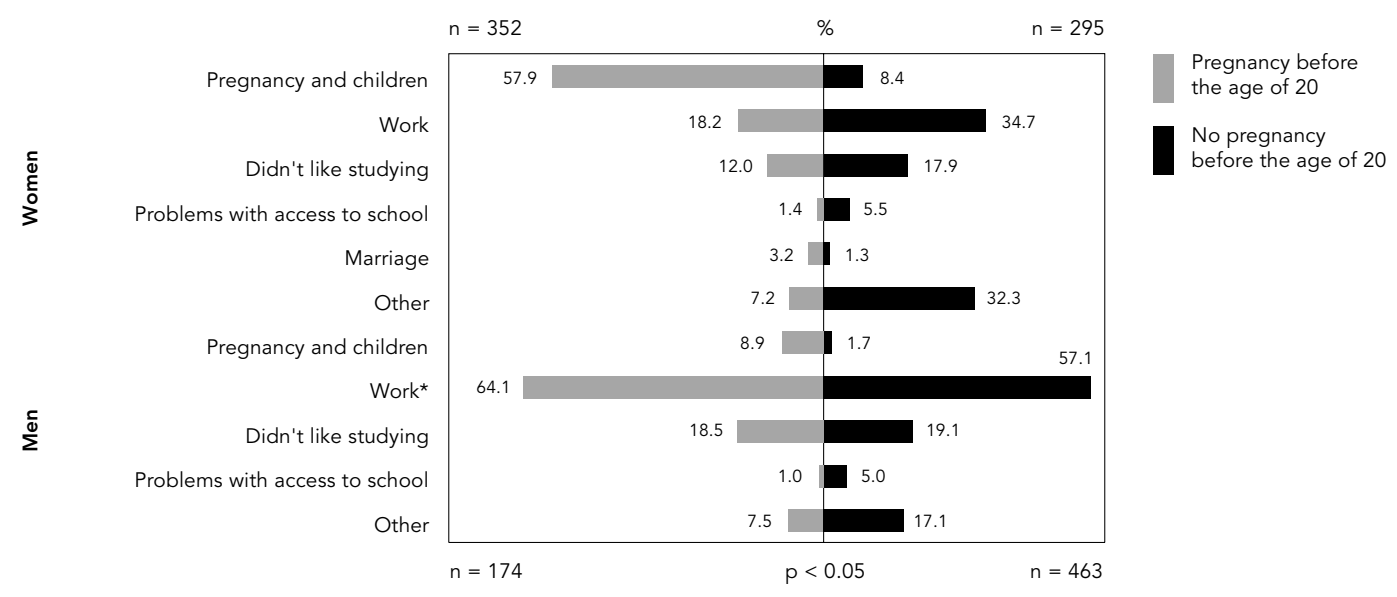

Source: GRAVAD Research Project, 2002

* Including military service.

pose that major recall problems did not occur, due to the importance of the target events: pregnancy and key events in school trajectories. In addition, the research subjects who are still quite young are at the beginning of their reproductive careers, and the few events that ocurred took the time that close to the interview took place. Furthermore, characteristics of the research instrument with the inclusion of questions on the occurrence of pregnancy and its outcome at different moments in the questionnaire allow comparing the answers. However, intentional errors may have occurred, especially related to reported pregnancy and abortion. The fact that abortion is both illegal and morally censured in Brazil may have favored non-reporting of a pregnancy with this outcome, especially by girls 15 . Boys would supposedly have less difficulty in declaring an abortion, since pregnancy is external to them, even though precisely for this reason their information on their partners' pregnancy tends to be less precise and more inconsistent.

The choice to characterize school trajectories using school temporary dropout as the main marker was due to the fact that in the stratified analysis, age-grade lag appears as a mass phenomenon, and temporary dropout was the characteristic that most clearly distinguished the subgroups of youth.
By seeking to reconstruct the order of the events over time, the idea was to fill a gap in the literature. However, due to the study's crosscutting design, one cannot completely guarantee the information's reliability as to the order in which the target events occurred. We believe that the information reported by the youth is reasonably credible, but this should be confirmed through longitudinal studies.

The results of this study indicate that young people with lower monthly per capita family income, blacks, and those whose mothers have less schooling are overrepresented in terms of their own irregular school trajectory, confirming the widespread striking social inequalities in Brazil. Such information lends visibility to processes affecting this youth segment and their limited possibilities for completing primary education. This is the prevailing reality for significant contingents of youth in the Brazilian school system, whereby schooling rates among 18-24-year-olds decreases in proportion to declining monthly per capita family income 16 .

Although data from the last population census indicate that the 20-24-year group shows the largest increase in school enrollment, from $18.3 \%$ in 1993 to $26.8 \%$ in 200316 , there was a delay in school turnover as shown by the high proportion of age-grade lag and of young people still attending elementary school. Part of 
School dropout in youth 20 to 24 years of age who reported pregnancy during adolescence, according to selected characteristics, Porto Alegre, Rio de Janeiro, Salvador, Brazil.

\begin{tabular}{|c|c|c|c|c|c|}
\hline \multirow[t]{3}{*}{ Characteristics } & \multicolumn{4}{|c|}{$\begin{array}{l}\text { School dropout in relation to timing } \\
\text { of pregnancy in adolescence }\end{array}$} & \multirow[t]{3}{*}{ p-value } \\
\hline & \multicolumn{2}{|c|}{ Did not drop out } & \multirow{2}{*}{$\begin{array}{c}\text { Before } \\
\%\end{array}$} & \multirow{2}{*}{$\begin{array}{l}\text { During or after } \\
\%\end{array}$} & \\
\hline & $\mathrm{n}$ & $\%$ & & & \\
\hline \multicolumn{6}{|l|}{ Females } \\
\hline Overall proportion & 488 & 46.6 & 16.7 & 36.7 & \\
\hline Monthly per capita family income (R\$) & & & & & 0.0001 \\
\hline$\leq 180.00$ & 304 & 36.1 & 19.3 & 44.6 & \\
\hline$\geq 180.00$ & 184 & 62.6 & 12.7 & 24.7 & \\
\hline Mother's schooling & & & & & 0.0034 \\
\hline Incomplete elementary & 287 & 40.6 & 15.6 & 43.8 & \\
\hline Complete elementary & 80 & 53.2 & 14.4 & 32.6 & \\
\hline Secondary/University & 82 & 75.5 & 6.2 & 17.7 & \\
\hline Working during pregnancy* & & & & & 0.0198 \\
\hline No & 240 & 47.4 & 11.4 & 41.2 & \\
\hline Yes & 247 & 45.8 & 22.6 & 31.6 & \\
\hline \multicolumn{6}{|l|}{ Marital status } \\
\hline During pregnancy & & & & & 0.0004 \\
\hline Marital union & 131 & 30.5 & 29.2 & 40.3 & \\
\hline No marital union & 357 & 51.6 & 12.8 & 35.6 & \\
\hline Current & & & & & 0.0034 \\
\hline Marital union & 294 & 36.8 & 20.5 & 42.7 & \\
\hline No marital union & 194 & 58.2 & 12.1 & 29.7 & \\
\hline Pregnancy outcome & & & & & 0.0000 \\
\hline Child & 383 & 39.3 & 20.6 & 40.1 & \\
\hline Induced abortion & 65 & 84.3 & 2.3 & 13.4 & \\
\hline \multicolumn{6}{|l|}{ Males } \\
\hline Overall proportion & 269 & 41.5 & 18.1 & 40.4 & \\
\hline Monthly per capita family income ( $R \$)$ & & & & & 0.0017 \\
\hline$\leq 180.00$ & 127 & 26.0 & 19.4 & 54.6 & \\
\hline$\geq 180.00$ & 142 & 58.8 & 16.7 & 24.5 & \\
\hline Mother's schooling & & & & & 0.1699 \\
\hline Incomplete elementary & 123 & 39.2 & 15.2 & 45.5 & \\
\hline Complete elementary & 45 & 37.1 & 14.0 & 48.8 & \\
\hline Secondary/University & 79 & 60.8 & 16.1 & 23.1 & \\
\hline Working during pregnancy* & & & & & 0.0416 \\
\hline No & 84 & 54.6 & 6.2 & 39.2 & \\
\hline Yes & 182 & 36.9 & 22.4 & 40.7 & \\
\hline \multicolumn{6}{|l|}{ Marital status } \\
\hline During pregnancy & & & & & 0.4249 \\
\hline Marital union & 16 & 21.3 & 19.4 & 59.3 & \\
\hline No marital union & 252 & 44.0 & 17.2 & 38.8 & \\
\hline \multicolumn{6}{|l|}{ Current } \\
\hline Marital union & 89 & 32.5 & 16.5 & 51.0 & 0.2455 \\
\hline No marital union & 180 & 47.3 & 19.1 & 33.6 & \\
\hline Pregnancy outcome & & & & & 0.4341 \\
\hline Child & 109 & 37.8 & 19.2 & 42.9 & \\
\hline Induced abortion & 108 & 48.4 & 20.5 & 31.1 & \\
\hline
\end{tabular}

* Includes 42 females and 28 males who started working during pregnancy. Source: GRAVAD Research Project, 2002. 
the school performance in this group could be explained by the relationship between school and work, which merits discussion here.

It has been pointed out that the need to work early in order to contribute to the family income or even to ensure one's own financial survival and independence leads youth to relegate their studies to a secondary level or even to drop out of school. Still, this happens differently between the genders and between socioeconomic classes; young people who drop out of school regardless of whether they are working are the ones with low scholastic performance 17.

Boys generally start working earlier than girls, as confirmed by the current study's sample. However, participation in the work market was only associated with the type of school trajectory for girls, and even so, girls who already worked were the ones with the most regular school trajectories. This probably indicates the importance of schooling as a requisite for women's greater access to employment, thereby overcoming traditional gender inequalities in the work market. It also reflects the better family background and highlights that girls and boys from lower-income families face barriers that hinder their progress in "upward, quality educational trajectory” 10 (p. 211). The responsibility for housework is still a negative factor for girls' trajectories, both scholastic and professional.

Gender inequalities become even more evident when one investigates the alleged reason for interrupting one's studies. As in other studies 18,19 , pregnancy and children were the principal reasons cited by females for interrupting their studies. For males, work was the most important factor, although in some cases it may have been motivated by the need to assume responsibilities resulting from fatherhood. At any rate, a significant portion of young people drop out of school for other reasons, highlighting those related directly to access and remaining in school. In this case the differences between males and females are smaller, with similar dropout rates due to not enjoying studying (including those who claim they are discouraged by the school environment or by teacher) and problems with access to school.

The results show that youth with better school trajectory are more exposed to information on pregnancy and contraception in school, begin to date and have their sexual debut later, and are more likely to report use of contraceptive methods in their first sexual relations, highlighting the effect of schooling (but probably also of family background) on their sexual and reproductive decisions. Added to this is the fact that youth with more schooling are more exposed to control by the family and the school itself, in addition to having more clear-cut plans for their social emancipation, thus tending to postpone the desire to have a child. In this study, the proportion of pregnancies ending in induced abortion was higher in the group that had not dropped out of school, which could indicate the mutual exclusion of plans for school and childbearing.

Youth of both genders with the highest rates of repetition, definitive school dropout, age-grade lag, and inability to complete elementary education were the ones who reported the highest under-20 pregnancy rates. In addition, young people who were already more than seven years old when they enrolled in elementary school, and who thus started school with a lag, also showed a higher proportion of teenage pregnancy. According to the literature on this issue 8,22 , for youth living in poverty and with more limited chances of obtaining decent work, a pregnancy can provide social status involving greater respect and esteem from others, principally for adolescent girls, who often resort to it to confront family problems. On the other hand, girls from more privileged social strata, who are more pressured to finish their studies, tend to postpone plans to have a child. When they do become pregnant they tend to interrupt the pregnancy, and even when they have a child they are more likely to stick to their plans for social and family emancipation 21,22. This trend was corroborated by the present study, in which the majority of the girls who became pregnant during adolescence (and of the boys who got their partners pregnant) and whose mothers had complete secondary or university educations remained in school.

As described in other articles about the GRAVAD Research Project 20,23, in a major portion of the girls and boys with a history of pregnancy before 20 , this event occurred within a context of an established affective relationship, including young couples who were already together before the pregnancy. In fact, among the girls with a history of a marital union at the time of the pregnancy or interview, some $40 \%$ dropped out of school either during or after the pregnancy, indicating that marriage and motherhood overshadowed their plans for school and work.

Still, one must exercise caution when inferring a direct and immediate relationship between teenage pregnancy and poverty. According to Stern \& García 9, the age at which pregnancy occurs can not be attributed to poverty; in all likelihood, the young person's social and family background, expressed as unequal op- 
portunities, acts to expel the individual from school. Therefore, for a better understanding of the phenomenon, one must consider the social and historical context in which teenage pregnancy occurs 9 .

The results of the current study allow one to conclude that for the majority of low-income youth, teenage pregnancy and especially motherhood/fatherhood result from complex social processes that also tend to expel them from school or at least not favor their school trajectories. It is thus up to the school system to deal with differences among young people, orienting youth about sexuality and contraception, but also encouraging them to remain in school. It is equally necessary to adopt policies targeting young people who are out of school in order to foster their return to the school setting,

\section{Resumo}

Este artigo descreve a relação entre características da trajetória escolar de jovens mulheres e homens, e a ocorrência da gravidez na adolescência. Trata-se de um inquérito domiciliar de corte transversal, que entrevistou 4.634 jovens com idade entre 18 e 24 anos, escolhidos por meio de uma amostra estratificada em três estágios. Para este estudo foram selecionados aqueles com idade de 20 a 24 anos (65,6\%), sendo a proporção de gravidez na adolescência equivalente a 29,5\% para as mulheres e 21,4\% para os homens (quanto às suas parceiras). A iniciação sexual foi referida por $87 \%$ das moças e 95,3\% dos rapazes. A maioria dos jovens apresentou trajetória escolar irregular, sendo que 39\% permaneciam estudando na época. Quase metade das jovens que interrompeu os estudos pelo menos uma vez, relatou uma gravidez na adolescência. O motivo principal para interrupção dos estudos foi a gravidez $e$ filhos para as mulheres e o trabalho para os homens. O abandono escolar na ocasião da gravidez na adolescência foi referido por 40,1\% das moças cuja gravidez terminou em filho. Contudo, 20,5\% já tinham evadido antes de engravidar.

Gravidez na Adolescência; Escolaridade; Identidade de Gênero; Sexualidade offering alternatives for them to reconcile work and/or children. Health professionals known that with ideal nutritional and healthcare conditions, the risk of a pregnancy from 15 to 18 years of age is the same as that in higher age groups 9 . The health sector should thus be prepared to help youth, and especially adolescents, with orientation on the choice and use of contraceptive methods, ensuring their regular distribution. It is necessary to include males in reproductive health care, integrating protection for unplanned pregnancy with STD prevention. Shelter and care are needed for cases of confirmed pregnancies, ensuring prenatal and childbirth care, but also humane quality care for young women and their partners when a pregnancy is interrupted.

\section{Contributors}

M. C. C. Almeida was the field supervisor in Salvador, Bahia, participated in the construction and management of the database, statistical analysis and interpretation of the results, and drafting of the article. E. M. L. Aquino collaborated in all stages of the study design and coordination, including data analysis and drafting of the article. A. P. Barros contributed in the elaboration of indicators and data processing and statistical analysis.

\section{Acknowledgments}

The study Teenage Pregnancy: A Multi-center Study on Youth, Sexuality, and Reproduction in Brazil (GRAVAD Research Project) was originally prepared by Maria Luiza Heilborn (Instituto de Medicina Social, Universidade do Estado do Rio de Janeiro, Brazil - IMS/UERJ), Michel Bozon (Institut National d'Études Démographiques, France - INED), Estela M. L. Aquino (Programa Integrado de Pesquisa e Cooperação Técnica em Gênero e Saúde/Universidade Federal da Bahia, Brazil MUSA/UFBA), and Daniela Knauth (Núcleo de Antropologia do Corpo e Saúde/Universidade Federal do Rio Grande do Sul, Brazil - NUPACS/UFRGS). The study was carried out by three research centers, the Program on Gender, Sexuality, and Health (IMS/UERJ), the MUSA/UFBA, and the NUPACS/UFRGS. The main results of the survey have been published in the book O Aprendizado da Sexualidade: Reprodução e Trajetórias Sociais de Jovens Brasileiros (Rio de Janeiro: Garamond; 2006), which includes detailed information on the composition of the research team. The authors further acknowledge the financial support from the Ford Foundation (Fundação Ford), the Brazilian National Research Council (Conselho Nacional de Desenvolvimento Científico e Tecnológico), and the Coordinating Body for Training University Level Personnel (Coordenação de Aperfeiçoamento de Pessoal de Nível Superior), through their research grant programs. 


\section{References}

1. Calazans G. Cultura adolescente e saúde: perspectivas para a investigação. In: Oliveira MC, organizador. Cultura, adolescência e saúde: Argentina, Brasil, México. Campinas: Consórcio de Programas em Saúde Reprodutiva e Sexualidade na América Latina; 2000. p. 44-97.

2. Berquó ES. Brasil, um caso exemplar (anticoncepção e parto cirúrgicos) à espera de uma ação exemplar. Estudos Feministas 1993; 1:366-81.

3. Camarano AA, Araújo HE, Carneiro, IG. Tendências da fecundidade brasileira no século XX: uma visão regional. In: Giffin K, Costa SH, organizadores. Questões da saúde reprodutiva. Rio de Janeiro: Editora Fiocruz; 1999. p. 95-111.

4. Gupta N, Leite IC. Tendências e determinantes da fecundidade entre adolescentes no Nordeste brasileiro. Perspectivas Internacionais de Planejamento Familiar 2001; número especial:24-9.

5. Camarano AA. Fecundidade e anticoncepção da população jovem. In: Berquó E, organizador. Jovens acontecendo na trilha das políticas públicas. v. 1. Brasília: Comissão Nacional de População e Desenvolvimento; 1998. p. 109-33.

6. Heilborn ML. Gravidez na adolescência: considerações preliminares sobre as dimensões culturais de um problema social In: Vieira E, Fernandes MEL, Bailey P, McKay A, organizadores. Seminário Gravidez na Adolescência. Rio de Janeiro: Cidadania, Estudo, Pesquisa e Ação/Instituto de Pesquisa Econômica Aplicada; 1998. p. 23-32.

7. Souza MMC. A maternidade nas mulheres de 15 a 19 anos como desvantagem social. In: Vieira E, Fernandes MEL, Bailey P, McKay A, organizadores. Seminário Gravidez na Adolescência. Rio de Janeiro: Cidadania, Estudo, Pesquisa e Ação/Instituto de Pesquisa Econômica Aplicada; 1998. p. 74-91.

8. Sociedade Civil Bem-Estar Familiar no Brasil. Pesquisa Nacional sobre Demografia e Saúde. Rio de Janeiro: Sociedade Civil Bem-Estar Familiar no Brasil; 1996.

9. Stern C, García E. Hacia un nuevo enfoque en el campo del embarazo adolescente. In: Stern C, Figueroa JC, organizadores. Sexualidad y salud reproductiva: avances y retos para la investigación. México DF: El Colegio de México; 2001. p. 331-58.

10. Rosemberg F. Educação formal, mulheres e relações de gênero: balanço preliminar da década de 90. In: Bruschini C, Unbehaum SG, organizadores. Gênero, democracia e sociedade brasileira. 1a Ed. São Paulo: Editora 34; 2002. p. 195-224.
11. World Health Organization. Young people's health a challenge for society. Geneva: World Health Organization; 1986. (WHO Technical Report Series, 731).

12. Ministério da Saúde. Programa de Saúde do Adolescente: bases programáticas. Brasília: Ministério da Saúde; 1989.

13. Brasil. Lei n. 9.394, de 20 de dezembro de 1996. Estabelece as Diretrizes e Bases da Educação Nacional. Diário Oficial da União 1996; 23 dez.

14. Dubar C. Trajetórias sociais e formas identitárias: alguns esclarecimentos conceituais e metodológicos. Educ Soc 1998; 19:13-30.

15. Barreto TA, Campbell OMR, Davies JL, Fauveau V, Filippi VG, Graham WJ, et al. Investigating induced abortion in developing countries: methods and problems. Stud Fam Plann 1992; 23:159-70.

16. Instituto Brasileiro de Geografia e Estatística. Síntese de indicadores sociais, 2004. Rio de Janeiro: Instituto Brasileiro de Geografia e Estatística; 2005. (Estudos \& Pesquisas. Informação Demográfica e Socioeconômica, 15).

17. Madeira FR, Rodrigues EM. Recado dos jovens: mais qualificação. In: Berquó E, organizador. Jovens acontecendo na trilha das políticas públicas. v. 2. Brasília: Comissão Nacional de População e Desenvolvimento; 1998. p. 427-96.

18. Stevenson W, Maton KI, Teti, DM. School importance and dropout among pregnant adolescents. J Adolesc Health 1998; 22:376-82.

19. Faloppa CC, Sato DK, Souza EC, Valmórbida GA, Petrelli GS, Inoue HY, et al. Gravidez na adolescência: estudos de 50 casos atendidos na Maternidade Municipal de Londrina - PR. Semina 1994; 15:30-5.

20. Brandão ER, Heilborn ML, Aquino EML, Knauth DR, Bozon M. Juventude e família: reflexões preliminares sobre a gravidez na adolescência em camadas médias urbanas. Interseções: Revista de Estudos Interdisciplinares 2001; 3:159-80.

21. Monteiro S. Gênero, sexualidade e juventude numa favela carioca. In: Heilborn ML, organizador. Sexualidade: o olhar das ciências sociais. Rio de Janeiro: Jorge Zahar Editor; 1999. p. 117-45.

22. Dadoorian D. Adolescentes: porque elas querem engravidar? Femina 1996; 24:47-51.

23. Aquino EML, Heilborn ML, Knauth D, Bozon M, Almeida MC, Araújo J, et al. Adolescência e reprodução no Brasil: a heterogeneidade dos perfis sociais. Cad Saúde Pública 2003; 19 Suppl 2:S377-88.

Submitted on 14/Sep/2005

Final version resubmitted on $05 / \mathrm{Jan} / 2006$

Approved on 31/Jan/2006 